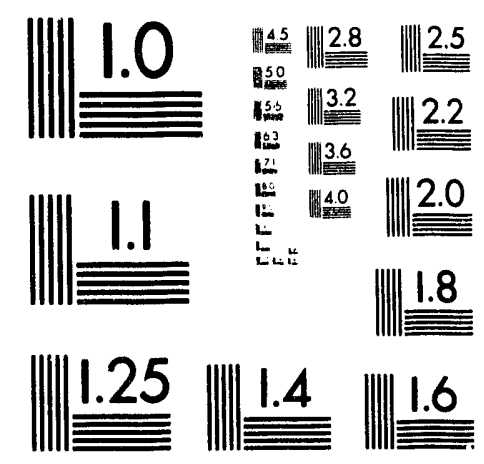



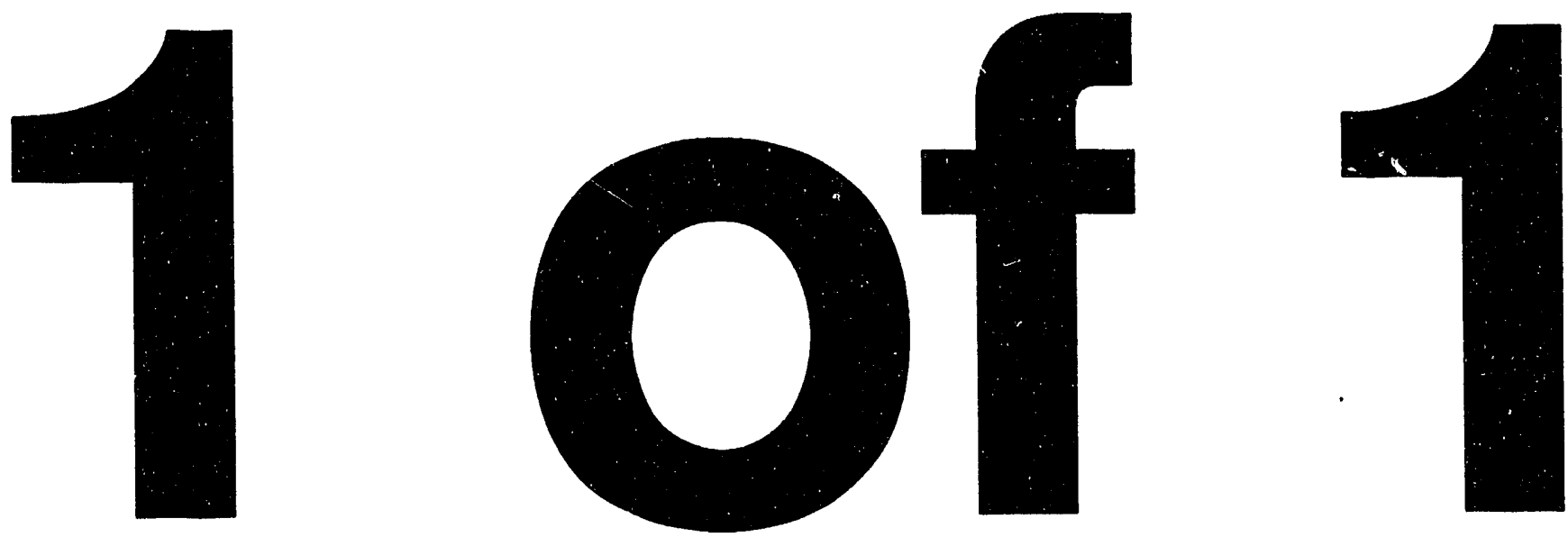
DPST $\mathbf{- 8 4 . 3 8 5}$

\section{ANALYSIS OF TECHNETIUM IN SRP URANIUM PRODUCT STREAMS}

b y

E.G. Orebaugh

E. I. du Pont de Nemours \& Company

Savannah River Plant

Aiken, South Carolina 29808

This report was prepared in connection with work done under Contract No.

DE-AC09-81SR0001 with the U.S. Department of Energy. By acceptance of this report, the publisher and/or recipient acknowledges the U.S. Government's right to retain a nonexclusive, royalty-free license in and to any copyright covering this report, along with the right to reproduce and to authorize others to reproduce all or part of the copyrighted report.

\section{MASTER}

DISTHBUTION OF THIS GGCUMFENT IS IINLIMITE! 


\section{DISCLAIMER}

This report was prepared as an account of work sponsored by an agency of the United States Government. Neither the United States Government nor any agency thereof, nor any of their employees, makes any warranty, express or implied, or assumes any legal liability or responsibility for the accuracy, completeness, or usefulness of any information, apparatus, product, or process disclosed, or represents that its use would not infringe privately owned rights. Reference herein to any specific commercial product, process, or service by trade name, trademark, manufacturer, or otherwise does not necessarily constitute or imply its endorsement, recommendation, or favoring by the United States Government or any agency thereof. The views and opinions of authors expressed herein do not necessarily state or reflect those of the United States Government or any agency thereof.

This report has been reproduced directly from the best available copy.

Available to DOE and DOE contractors from the Office of Scientific and Technical Information, P. O. Box 62, Oak Ridge, TN 37831; prices available from (615) $576-8401$.

Available to the public from the National Technical Information Service, U. S. Department of Commerce, 5285 Port Royal Rd., Springfield, VA 22161. 
D1stribution:

A. H. Peters, 703A
D. L. McIntosh, 703A
H. J. Groh, 703A
J. F. Ortaldo, 703A
L. M. Papouchado, 703A
J. K. Brown, 204F
W. E. Mancin1, 221F
J. T. Buckner, 704F
G. H. Sykes, 777-10A
J. G. McK1bben, 703H
R. E. Meadors, 221H
C. W. Jenk1ns, 221F

ACC.NO. 110054

J. A. Porter, 773A

R. M. Wallace, $773 A$

D. A. Orth, $773 A$

G. A. Burney, $773 A$

D. G. Karraker, $773 \mathrm{~A}$

J. R. W1ley, 773 A

R. M. Mobley, 773A

M. A. Ebra, $773 A$

A. E. Shook, 773A

D. D. Walker, 773A

J. R. Fowler, 773A

Progita(4). 773A

Apr11 6, 1984

Io: H. D. Harmon

From: E. G. Orebaugh gar

ARARTSIS OF TECHWTTOM II SRP ORATIUA PRODOCT STREAYS

\section{IITRODOCTION}

Technegfium (TC) 1s a wor fission product with a f1ssion yield siallar to ${ }^{90}$ Sr and $137 \mathrm{Cs}$. All traces of the natural element have disappeared due to decagover the earth's history. The for isotope present in cooled nuclear fuel 1o 99 TC with a half life of $2.12 \times 10^{5}$ gears. Th1s 180 tope decays via low energy (0.292Mev) beta entssion which is easly absorbed and contributea 11tele penetrating radiation hazarde in fuel reprocessing.

Because it 1s difficult to detect, the distribution of ${ }^{99}$ Ic in the $F$ and $B$ area process streams is not generally well knowa. An early report on Tc distribution was published in 1959. More recent studies have emphasized 1ts presence 1n SRP waste streame; its long half life makes it significant in the DWPP progran.

\section{SURART}

Previous studies have shown that significant fraction of Tc follows uraniue through the solvent extraction process. Thls study was conducted to analgze the ${ }^{99}$ TC content of SRP uraniue product streams, to assess any hazard due to 99 Te and to evaluate the impact of future higher byraup fuels on 99 Tc levels $1 \mathrm{a}$ urantun products. Th1s sumary report presents 99 Tc assays in uraniun streans in F and $B$ areas, relates these concentrations to solvent extraction conditions in the two areas, and compares the incremental radioactivity fron ${ }^{99}$ Tc in the product streams to the uraniun 1tself. Presently the radloactivity contributed by ${ }^{99}$ Te 1s small relative to uranium. The proposed production using Mark 15 asseablies will also result in negligible increase in radloactivity due to ${ }^{99} \mathrm{TC}$. 


\section{DISCOSSION}

\section{Production of TC}

The production rates of TC clted in this study are based on SRP reactor throughput during fiscal year $1983^{3}$. For F area, burnup of MK-31 targets(0.27 $235 \mathrm{U}$ ) averaged $208 \mathrm{MWD} / \mathrm{MrU}$. Technetiun production can be calculated, 81 ven the fission yield 1s 6.1\%:

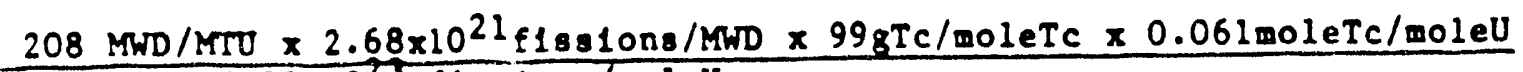
$6.02 \times 10^{23}$ f18s 1008/moleU

- $5.6 \mathrm{gTc} / \mathrm{MrU}$ or $5.6 \times 10^{-6} \mathrm{gTc} / \mathrm{gU}$ or $5.6 \mathrm{ppmTc} / \mathrm{U}$

For R-area the calculations are similar but require the weighted burnup 0 f MR-16 and $M-22$ drivers. When the welghted buraup is expressed in terms of $8350 / 8 \mathrm{U}$ the result 1s $31.1 \%$. Therefore the ${ }^{99}$ Tc production 18 given by:

$$
0.311 \times 99 / 235 \text { gmoleTc/gmoleU } \times 0.061=8 \times 10^{-3} \mathrm{gTc} / 8 \mathrm{U} \text { charged }
$$

But since we wh to reference the Tc to the residual total uranim:

$$
8 \times 10^{-3} /(1-.311)-1.2 \times 10^{-2} \quad 8 \mathrm{Tc} / 8 \mathrm{D} \text { residual or } 12000 \mathrm{ppmTc} / \mathrm{O}
$$

These galculations show that B-area processes uranlum with over 2000 times as much $99 \mathrm{TC} / 80$ as F-area. Because P-area processes about 200 t1mes as much urantua per year, only about 10 times as wuch Ic is handled in H-area but at wuch higher concentrations. This regult agrees with information fron D. A. Sharp, NED.

\section{Distribution of Te}

Upon dissolution, the Tc produced in 1rradiated fuels and targets is oxidized to the pertechnetate $100\left(\mathrm{TCO}_{4}^{-}\right)$. Th1 anlon aight be expected to be refected to the high activity waste during solvent extraction in F-area or B-area. Bowever, some TC 1s known to follow 0 through the process. Siddall attributed this behavior to a subatitution of pertechnetate for nitrate in the extracted urangl nitrate.

The distribution of Ic throughout the solvent extraction procese in both separat1ons areas was laveetlgated by analyols of those product streans in which Tc would be expected frov its co-extraction with uranium. Results frovanalyzing the product streane are presented in Table 1. The 1 ppmTc/U found in the 180 concentrate and A-11ne oxide Indlcates that about $18 \%$ of the TC laput to P-area is carried into the uranium oxide product. The 80 pparc/U observed $1 \mathrm{n}$ the $\mathrm{B}$-area product awounts to only $0.7 \%$ of the calculated input to the enriched uranius process. 
Table 1

\begin{tabular}{|c|c|c|}
\hline Process stream sampled & area & assay ppotc/u \\
\hline IEU evaporator overheads & F-area & n11 \\
\hline LEU concentrate ( $420 \mathrm{8} / 1$ U In tank 17.7$)$ & F-area & $0.99 \mathrm{ppm}$ \\
\hline $\mathrm{UO}_{3}$ product from A-line denterator & F-area & $1.08 \mathrm{ppm}$ \\
\hline $1 D F$ adfusted feed $(10 \mathrm{~g} / 1$ in tank 17.5$)$ & $\mathrm{B}$-area & $78 \mathrm{PPm}$ \\
\hline LEU enriched urantum product ( tank 14.5) & H-area & $82 \mathrm{PPW}$ \\
\hline
\end{tabular}

Analysis of the uranlumproduct strean frow R-area was made more difflcult by the 100 fold Increase in $235 \mathrm{U}$ content. The neutron activation method employed for Tc analysis is susceptible to error caused by flssion of any residual fissile materials. The anton exchange separation of Tc from the uranium was only warglnally sufficlent with highly enrlched uranium. Therefore the siallarity between the IDF and the LEU results fron B-area ohould not be used to lndicate. that the coextration of TC in the second uranium cycle was highly efficlent. Attempts to assay TC in the waste streams falled due to contanination by 129 I. Since our primary purpose was to assay the uranium product, no further effort was expended on the waste strean analyols.

There was an In1t1al concern that Te alght volat111ze v1a 1ts ac1d anhydr1da, but the IEU evaporator overheade In F-area were found to have Insignificant TC content. This observed low volatility is to be expected for a highly lonized dilute ac1d. Prior studies 1,5 have show that volatilization of Tc during denttration in the A-11ne was no concern even though temperatures far exceed the bolling polnt of $\mathrm{IC}_{2} \mathrm{O}_{7}$.

\section{The Solvent Bxtraction Behavior of Technatiun}

The great difference in the solvent extraction behavior of Tc between the $P$ and H-areas can be understood frou the original published work of S1ddall and the recent studles $6-10$ by other nuclear chenletry groups.

There 18 general agreement that pertechnetic acid partitions between TBP extractant and aqueous solutions in a manner which 18 acid dependent as represented by the following equation:

$$
\mathrm{TCO}_{4}^{-}+\mathrm{H}^{+}+3\left(\mathrm{TBP}_{\text {org }}\right)-\cdots \mathrm{ErCO}_{4} \cdot 3 \mathrm{TBP}_{\text {org }}
$$

However, the extraction 1nto the organic phase in the presence of uranium is many times that of pertechnetic acid alone. The wechanisa for this enhanced extraction of TC 1s belleved to follow the equation: 


$$
\mathrm{UO}_{2}\left(\mathrm{NO}_{3}\right)_{2} \cdot 2 \mathrm{TBP}+\mathrm{TCO}_{4}^{-}-\cdots-\mathrm{UO}_{2}\left(\mathrm{NO}_{3}\right) \mathrm{TCO}_{4} \cdot 2 \mathrm{TBP}+\mathrm{NO}_{3}^{-}
$$

Because extraction by this second mechanisw is more effective than by the first, and since the second mechanism does not explicitly depend upon the acid concentration, 1t follows that extraction of the pertechnetate is proportional to the awount of uranyl nitrate TBP adduct ${ }^{9-11}$.

Since the relative uranlum loadings $1 \mathrm{n}$ both $\mathrm{F}$ and $\mathrm{H}$ area $1 \mathrm{~A}$-banks are approxiately equal, then the $7.5 \% / 30 \%$ ratio of the TBP should limit the entralned TC in B-area IAP to one fourth the amount in B-area LAP. The assumption is reasonable since the banks are operated with the dusl constraints of low uraniun loses (excess TBP to assure efflclent $U$ extraction) and high flssion product decontamination (achieved by high $U$ saturation of the extractant). Agaln, if the relative loading in the second uraniun cycles of both areas are nearly equal one would expect the overall entralnment of Tc to be one sixteenth (one fourth in the first cycle tioes one fourth in the second cycle) as great in H-area U product as the F-area. The results in Table 1 actually give a rat10 of 27. In v1ew of the assumptions made, the agreement between predicted and observed ratios provides reasonatie support for siddall's model.

\section{Radiat100 Due to ${ }^{99}$ Te in Draniw Fiofshing}

Radiation considerations due to ${ }^{99}$ Tc In uranium products arise from elther increased expusure to personnel lavolved in $U$ flnishing or in subsequent operations if the uranium is asaued to be free of radloactive contamiants.

For the purpose of this analysis the radioactivity contributed by ${ }^{99}$ TC contanination was compared to the radloactivity of 1 ts uranlun host. The radloactivity of the $P$ area uranium product under current operations 18 almost entirely due to $238 \mathrm{U}$. Since $235 \mathrm{v}$ has a shorter half 11 fe than $238 \mathrm{~V}$, enriched uranlum has a greater radiological hazard on a welght basis. In addition enriched fuels accumulate $236 \mathrm{U}$ with each cycle through the reactor. The $236 \mathrm{O}$ adds sigaificantly to the radiological hazard of $U$ but since 1 ts abundance depends upon the radigfton hlstory of the fuel, the Tc hazard was noralized to the sum of $238 \mathrm{U}$ and $235_{\mathrm{O}} 1$ sotopes onls.

If doubling of the radlologlcal hazard of the host uranlum due to Tc contaninaton is considered a threshold of algnificance, then the P-area A-11ne product mus be below $19 \mathrm{ppwTC} / 0$ while the H-area product cag be as high as $125 \mathrm{ppoTc} / \mathrm{U}$ without doubling the specific activity (excluding 236 0 ) of the end product. This study shows that both $P$ and $B$ areas are within this criteria and can be expected to remaln 80 with the current flowsheets and nuclear materials mixture.

The proposed processing of MR-15 assemblies in P-area (1rradiated to 65.5 $\mathrm{KMWD}$ (charge) would result in only a 147 incresse in activity due to Tc assuning the current flowsheet carry through rates. Th1s result is surprising since the MR-15 assemblles comblne the functions of enrlched driver and target of the current reactor charges and wight be expected to have a higher radiological signiflcance due to TC. However, the shielding calculations made by $P$. B. Parks ${ }^{4}$, NED, for the 18otople mixture expected after the programed 1rradiation show that the short irradiations necessary to 11 mit the production of 240 Pu comblned with the only slightly enriched $235_{0}$ content limit the relative specific 
activity of the Tc fission products. Again this is conservative since the ${ }^{236} \mathrm{U}$ 1sotopes are not included.

\section{CORCLUSIONS}

Technetium f1ssion products are a signiflcant contaminant of uranlum recovered frow nuclear fuels and targets using solvent extraction processes based upon TBP. However, the radiological significance of this contaminant is small due to 1 ts long half-life and it low energy enlsslons which are highly shlelded by the uranlum host. Current operations produce a uranium product in both $P$ and H-aress in which the IC contamination contributes 1 ess to the radlological activity than the bulk uranium. Slmilarly, future processing of MR-15 fuels in $P$ area will present no increase in hazards due to Tc content. Thls study has determined that uranium product contamination by $T c$ lo not casual but lo predictable for a given flowsheet and "burn-up" h1story of the fuel beling processed. 


\section{RBTBRALCLS}

1. T. A. S1ddal1. "Behavior of Technet1un in the Purex Process." DP-364, Apr11 1959.

2. W. R. MCDonell to P. L. Roggenkamp. "Cr1ter1a and Costs for Technet1um-99 Recovery frow H1gh Level Waste Salt", DPST-83-608, June 21, 1983.

3. I. M. MaCafee. Personal assistance to E. G. Orebaugh in estimating SRP TC product10n. 8/11/83.

4. D. A. Sharp and P. B. Parks. Nuclear Englneering Division, SRL Assistance to E. G. Orebaugh in extracting 1sotoplc data from computer calculations which model SRP's production reactors.

5. I. J. Urza and D. C. R111an "Laboratory and P1lot Plant Studles on the Conversion of Oranyl Nitrate to Uranium Hexaflourlde." published in Act1n1de Separations, Navrat1l and Schulz editors, ACS Symposiun No. 117.

6. D. J. Pruett. "The Solvent Extraction Behavior of Technetium. Part I, The N1tric Ac1d/ Tr1-a-butyl Phosphate Systen", Rad1ochenica Acta 28, 153(1981) "Part II, The Rydrochloric Ac1d/ Tr1-n-butyl Phosphate Systen", 1bid. 29,107.

7. R. H. Lleser, A. Rruger, and R. N. S1ngh. "Extraction of TC(VII) by Tr1-nbutyl Fhosphate", Radiochenica Acta, 28, $97(1981)$.

8. T. N. Jassin, J. O. L11Jenzin and G. Persson. "Sgnerg1st1c Rffect of Oranyl Nitrate on the Extraction of Pertechnet1c and Perrhen1c Ac1ds by TBP Solut1ona fron N1tric Ac1d", Radiochealca Acta 33, 163(1983).

9. B. Ranellakopulos and C. P. Ron18. "On the Extraction Behav10r of Technet1un with Respect to the Purex Process", Radiochenica Acta 33, 169(1983).

10. T. N. Jassin, J. 0. L11 Jenz1n, R. Lundqv1st, and G. Persson. "Coextraction of Uraniun and Technetiun in TBP Syotena", Presented at the International Solvent Extraction Conference, Denver CO, 1983.

11. J. 0. L11jenzin Personal Commulcations and preprint of a paper to appear In Solvent Extraction and Ion Exchange (1984). 

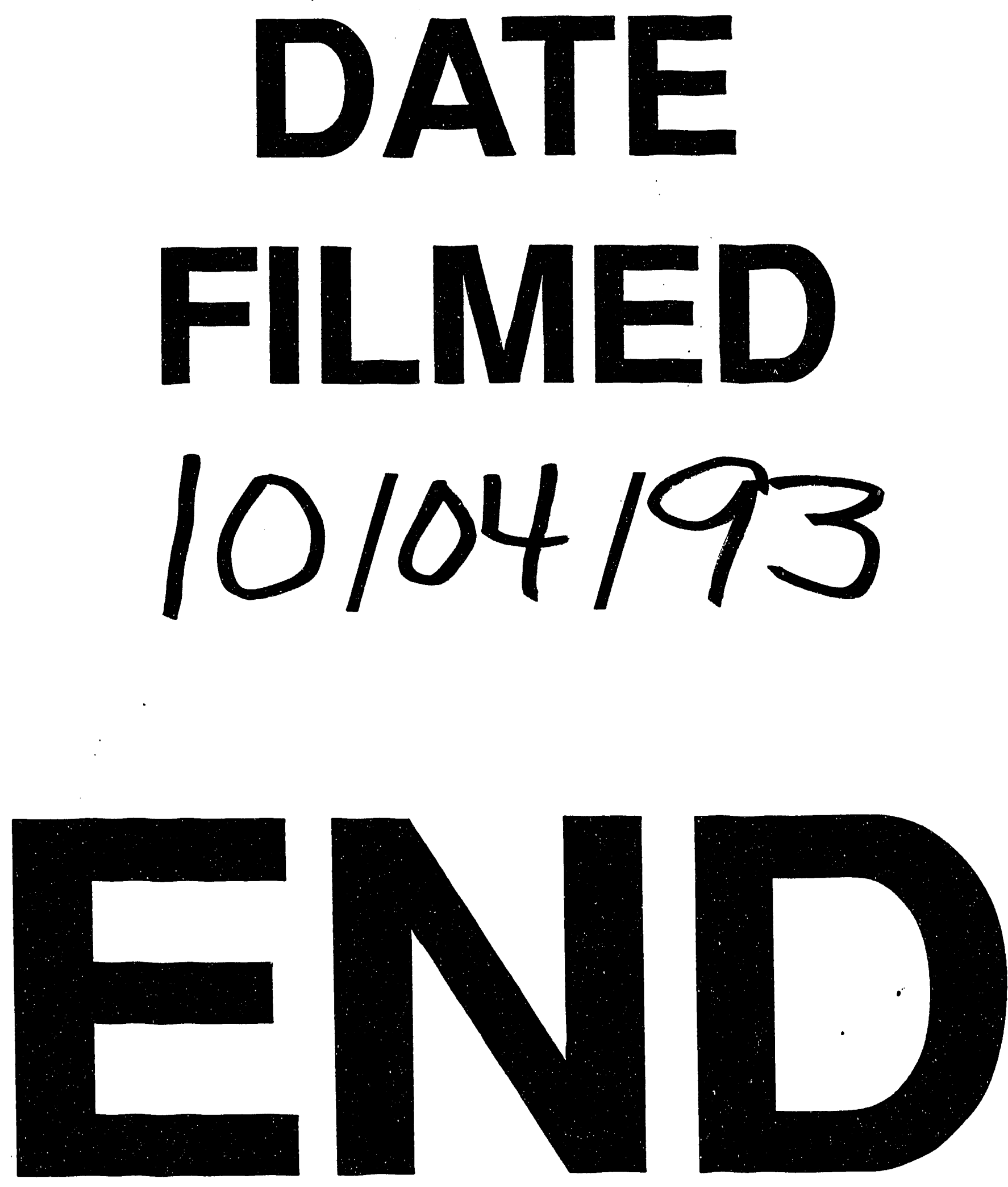
